\title{
CONVOCATORIA DE MANUSCRITOS I SEMESTRE 2015
}

El grupo editor de la revista académica y científica "Policía y Seguridad Pública", una iniciativa del Centro de Investigación Científica de la Academia Nacional de Seguridad Pública (República de El Salvador); invita a especialistas y académicos nacionales e internacionales a participar con manuscritos y trabajos para su séptimo número que será publicado en el primer semestre de 2015. Este séptimo número desarrollará la temática "Pandillas y Extorsiones", en el que se recojan aportes fundamentales para la comunidad de analistas y planificadores del área de la seguridad. Por ello son requeridos artículos científicos y estudios estratégicos originales e inéditos; sin publicaciones previas y portadores de nuevo conocimiento y propuesta que impacten en el quehacer de los decisores públicos de este sector.

Las propuestas deberán atender el programa de investigación referido a "Estructuras delictivas, delitos y modalidades de violencia y criminalidad". Desarrollando una idea fuerza en la cual se atiendan enfoques sobre los grandes ilícitos así como las perspectivas de organizaciones criminales emergentes que median en economías subterráneas. Todo lo anterior como contribución a las comunidades de seguridad e inteligencia de El Salvador y la región Mesoamericana con el propósito de fortalecer la profesionalización policial, los esfuerzos de inteligencia y la formulación de políticas públicas inherentes en el nivel más alto de la planeación estatal.

Los estudios deberán establecer aproximaciones a las siguientes temáticas estratégicas:

1. Formas de lucha y entrenamiento en las pandillas transnacionales salvadoreñas.

2. Análisis de liderazgos criminales.

3. Evaluación crítica y estratégica de la tregua entre pandillas salvadoreñas.

4. Mapeo estratégico de pandillas en Honduras, México, Guatemala y Estados Unidos de América.

5. Análisis de coordinación de estructuras criminales en el Triángulo Norte Centroamericano.

6. Análisis de la guerra entre pandillas y otras escisiones orgánicas.

7. Economía subterránea de estructuras criminales y la lógica de la extorsión.

8. Prospectiva del desarrollo futuro de las pandillas.

9. Poblaciones reclusas con filiaciones a pandillas transnacionales.

Los trabajos:

1. Deben enviarse a revista.seguridad@ansp.gob.sv atendiendo las normas de publicación establecidas por la revista, que serán remitidas a los interesados por correo electrónico.

2. Se recibirán hasta el lunes 02 de febrero de 2015.

3. Serán publicados una vez existan dictámenes favorables de los pares evaluadores.

4. El español y el inglés son las lenguas en las que pueden ser remitidas las propuestas académicas. Otra deberá consultarse con anticipación con el grupo editor.

5. Podrán ampliarse y proponerse otras temáticas estratégicas, siempre y cuando no riñan con los programas de investigación vigentes y sean autorizados por el grupo editor.

Juan Carlos Morales Peña

Editor Jefe

juan.morales@ansp.gob.sv
Augusto López Ramírez

Editor Asistente

augusto.lopez@ansp.gob.sv 


\section{CALL FOR MANUSCRIPTS \\ FIRST SEMESTER 2015}

The editors of the academic and scientific journal "Police and Public Security", an initiative of the Scientific Research Center of the National Public Security Academy (El Salvador), invites national and international specialists and scholars to participate with manuscripts and papers for the seventh issue to be published during the first semester of 2015. This seventh issue will focus on "Gangs and Extortion" and contain contributions that are of fundamental importance for the community of security analysts and planners. So scientific articles and original and previously unpublished strategic studies are required to contribute new knowledge and proposals capable of having an impact on the work of public decisionmakers in this sector.

Proposals should address research relating to "Criminal structures, crime and types of violence and criminality". They should develop a core idea which focuses on serious crime as well as the perspectives of emerging criminal organizations that participate in underground economies. This will contribute to the security and intelligence communities of El Salvador and the Mesoamerican region in order to strengthen police professionalization, intelligence efforts and public policy formulation at the highest level of state planning.

Studies should consist of approaches to the following strategic issues:

1. Forms of struggle and training in Salvadoran transnational gangs

2. Analysis of criminal leadership

3. Critical and strategic evaluation of the truce among Salvadoran gangs

4. Strategic mapping of gangs in Honduras, Mexico, Guatemala and the United States

5. Analysis of criminal structure coordination in the Northern Triangle of Central America

6. Analysis of gang warfare and other functional divisions

7. Underground economy of criminal structures and the logic of extortion

8. Prospective for the future development of gangs

9. Prison populations with transnational gang affiliations

Submission process:

1. Manuscripts should be sent to revista.seguridad@ansp.gob.sv in accordance with journal publication standards which will be sent to interested parties via email.

2. The deadline is Monday February 2, 2015.

3. They will be published once approved through a peer review process.

4. Academic proposals may be sent in Spanish or English. For any other languages requests should be sent to the editors in advance.

5. Papers may include other strategic themes, provided that there is no clash with current research programs and that they are authorized by the editors.

Juan Carlos Morales Peña

Editor in Chief

juan.morales@ansp.gob.sv
Augusto López Ramírez

Assistant Editor

augusto.lopez@ansp.gob.sv 